\title{
Demographic description and outcomes of a metropolitan network for myocardial infarction treatment
}

\author{
Descripción demográfica y desenlaces de una red metropolitana de atención para el \\ infarto agudo de miocardio
}

\author{
Rodrigo Gopar-Nieto ${ }^{1 *}$, Diego Araiza-Garaygordobil', Grecia I. Raymundo-Martínez", \\ Pablo Martínez-Amezcua², Alejandro Cabello-López³3, Daniel Manzur-Sandoval'1', Nancy L. Chávez-Gómez¹, \\ Arnoldo E. Loáisiga-Sáenz¹, Luis A. Baeza-Herrera1, Carlos A. Dattoli-García1, Leticia A. Gallardo-Grajeda1, \\ Cynthia N. Jackson-Pedroza', Brandon Salas-Teles ${ }^{1}$, and Alexandra Arias-Mendoza ${ }^{1}$ \\ ${ }^{1}$ Coronary Unit, Instituto Nacional de Cardiología "Ignacio Chávez", Mexico City, Mexico; ²Department of Epidemiology, Johns Hopkins Bloomberg \\ School of Public Health, Baltimore, USA; ${ }^{3}$ Unidad de Investigación de Salud en el Trabajo, Centro Médico Nacional Siglo XXI, Mexico City, Mexico
}

\begin{abstract}
Objective: The objective of the study was to describe the myocardial infarction treatment network and compare in-hospital mortality in patients undergoing either primary angioplasty or pharmacoinvasive strategy in Mexico City and a broad metropolitan area. Methods: Cohort study including patients with ST-elevation myocardial infarction. We recorded demographic and clinical data, laboratory tests and in-hospital mortality in patients that underwent primary angioplasty and pharmacoinvasive strategy. Kaplan-Meier analysis was used to assess mortality and Cox-regression assessed mortality risk factors. Results: Three hundred forty patients from a network of 60 hospitals and 9 states were analyzed. Of the total population, 166 were treated with pharmacoinvasive strategy and 174 with primary angioplasty. Door to thrombolytic time was 54 min and door to wire crossing time was $72.5 \mathrm{~min}$; no differences in total ischemia time were demonstrated. No differences for in-hospital mortality (6.3\% vs. $5.4 \%, p=0.49)$ were found when comparing pharmacoinvasive and primary angioplasty groups. The main predictors for in-hospital mortality were: glucose $>180 \mathrm{mg} / \mathrm{dl}$ (HR 3.73), total ischemia time > $420 \mathrm{~min}$ (HR 3.18), heart rate > $90 \mathrm{bpm}$ (HR 5.46), Killip and Kimball > II (HR 11.03), and left ventricle ejection fraction < 40\% (HR 3.21). Conclusions: This myocardial infarction network covers a large area and constitutes one of the biggest in the world. There were no differences regarding in-hospital mortality between pharmacoinvasive strategy and primary angioplasty. Pharmacoinvasive strategy is an effective and safe option for prompt reperfusion in Mexico.
\end{abstract}

Key words: Myocardial infarction. Thrombolytic therapy. Angioplasty. Mortality.

\section{Resumen}

Objetivo: Describir la red de atención de infarto agudo de miocardio y comparar los desenlaces intrahospitalarios en pacientes tratados con angioplastía coronaria o estrategia farmacoinvasiva en la Ciudad de México y su área metropolitana. Métodos: Estudio de cohorte que incluyó pacientes con infarto agudo de miocardio con elevación del segmento ST. Se recabaron datos demográficos y clínicos, asi como estudios de laboratorio y mortalidad intrahospitalaria en los pacientes que fueron tratados

Correspondence:

${ }^{*}$ Rodrigo Gopar-Nieto

E-mail: rodrigogopar@gmail.com
Date of reception: 25-03-2020

Date of acceptance: 12-04-2020

DOI: 10.24875/ACME.M21000218
Available online: $20-01-2021$ Arch Cardiol Mex (Eng). 2021;91(2):138-148 www.archivoscardiologia.com 2604-7063 / @ 2020 Instituto Nacional de Cardiología Ignacio Chávez. Published by Permanyer. This is an open access article under the CC BY-NC-ND license (http://creativecommons.org/licenses/by-nc-nd/4.0/). 
con angioplastía coronaria o estrategia farmacoinvasiva. Se realizó un análisis de Kaplan-Meier para describir la mortalidad y un modelo de regresión de Cox para evaluar los factores asociados a mortalidad. Resultados: Se analizaron 340 pacientes provenientes de una red compuesta por 60 hospitales. Del total de la población, 166 fueron tratados con estrategia farmacoinvasiva y 174 con angioplastía primaria. El tiempo puerta-aguja fue $54 \mathrm{~min}$. y el tiempo puerta-dispositivo de 72.5 min.; no se encontraron diferencias en el tiempo total de isquemia. Además, no existieron diferencias en la mortalidad intrahospitalaria (6.3\% vs. $5.4 \%, p=0.49)$ al comparar la estrategia farmacoinvasiva y la angioplastía primaria. Los principales predictores de mortalidad intrahospitalaria fueron: glucosa > $180 \mathrm{mg} / \mathrm{dl}$ (HR 3.73), tiempo total de isquemia > $420 \mathrm{~min}$. (HR 3.18), frecuencia cardiaca > 90 Ipm (HR 5.46), Killip and Kimball > II (HR 11.03) y fracción de eyección < 40\% (HR 3.21). Conclusiones: En esta red de atención al infarto agudo de miocardio no se encontraron diferencias en la mortalidad intrahospitalaria entre la estrategia farmacoinvasiva y la angioplastia primaria. La estrategia farmacoinvasiva puede ser una alternativa efectiva y segura para lograr reperfusión adecuada en México.

Palabras clave: Infarto de miocardio. Terapia trombolítica. Angioplastia. Mortalidad.

\section{Introduction}

Optimal timing for reperfusion in ST-segment elevation myocardial infarction (STEMI) reduces infarct size, prevents, and delays ventricular remodeling and increases survival ${ }^{1-3}$. In spite of this, a big proportion of patients, especially in low-income countries do not receive reperfusion promptly or receive it lately.

Clinical practice guidelines recommend two main strategies for reperfusion in STEMI: primary percutaneous coronary intervention (PPCl) and pharmacoinvasive strategy $(\mathrm{PS})^{1-4}$. PPCl consists in an urgent recanalization of the obstruction in the lumen of the affected coronary artery by means of a balloon or stent, without previous administration of a fibrinolytic agent. It has been demonstrated that coronary flow can return to normal in $90 \%$ of the cases, while for fibrinolysis flow is only restored in about $50-60 \%^{5-12}$. The success of reperfusion depends on many factors such as the time of onset of symptoms, the ability and experience of the operator and resource availability for the procedure ${ }^{12-15}$.

There is a problem with the availability of $\mathrm{PCl}$ centers in many parts of the world, as it has been stated in other studies ${ }^{16-18}$. To overcome these difficulties, PS consists in the administration of a fibrinolytic agent at first moment after diagnosis of STEMI, followed by a coronary intervention in the next 3-24 $\mathrm{h}$. This practice has reduced reinfarction and recurrent ischemia compared to medical treatment alone ${ }^{18}$. The STREAM trial demonstrated that the PS, together with contemporary antithrombotic therapy (clopidogrel, aspirin, and enoxaparin), has the same efficacy and safety than $\mathrm{PPCl}^{19}$. Other trials stand out the ability to overcome the social and geographic limitations ${ }^{16,20-22}$.

Mexico City and its metropolitan area constitute one of the most populated urban areas in the world ${ }^{23}$. The peculiar social and economic problematics of our country, together with a high population density, makes it difficult to treat STEMI in optimal timing so to accomplish guidelines goals represents a big challenge ${ }^{24}$. Therefore, the means of this study were to compare in-hospital mortality in patients taken to PPCl against those taken to PS in Mexico City and a large metropolitan area with the goal to establish the efficacy of PS in a real life setting.

\section{Methods}

A cohort from the PHASE-MX trial was taken, which included all patients from both genders, between 18 and 80 years of age, with a diagnosis of STEMI, that were admitted to the Emergency Department and Coronary Care Unit of the Instituto Nacional de Cardiología, from April 1, 2018, to March 31, 2019. The myocardial infarction definition used in this study was the one proposed by the European Society of Cardiology and Thygesen et al., ${ }^{1,2}$

At admission, the following data were collected: age, gender, date of admission, the presence of diabetes mellitus, systemic arterial hypertension, smoking, chronic kidney disease, obesity, previous history of myocardial infarction, previous revascularization, vital signs, TIMI, GRACE, and CRUSADE scores, blood biometrics, blood glucose, troponin, NT proBNP, total ischemic time, first medical contact time, door-to-needle time, door-to-wire crossing or device time, medical treatment before reperfusion, time to PS, and treatment success. In this study, all the patients from the PS group received fibrinolysis at their first medical contact center and angiography was done at Instituto Nacional de Cardiología, both decisions were made according to the medical staff's discretion. Afterward, we made an in-hospital follow-up where mortality and date of home discharge were registered. 
Statistical analysis: all tests were done in STATA v13 (StataCorp LP, College Station, Tx). Quantitative variables were analyzed with descriptive methods depending on their distribution, corroborated by the Shapiro-Wilk test. Variables with a normal distribution were described with mean value and standard deviation. Otherwise, median and interquartile ranges were used. Taking into consideration the normality of each quantitative variable, an analysis with Student's $t$ and U Mann-Whitney tests was performed. Qualitative variables were described through frequencies and percentages, while for the bivariate analysis $\chi^{2}$ or Fisher's test were performed depending on the number of events. For the survival analysis, tables and Kaplan-Meier curves were made to describe mortality in both groups. Differences between survival times for both treatment groups were compared with log rank test. Cox regression models, adjusted, by sex and age, were built to determine the main predictors of in-hospital mortality in patients treated with both strategies. A $p<0.05$ was considered as statistically significant.

Furthermore, for the descriptive analysis, we created a map of the hospitals that are part of our STEMI network. All hospitals were geocoded by finding their latitude and longitude using Google Maps. The coordinates were recorded in a separate datasheet. We used QGIS 3.10 (2019, QGIS Geographic Information System. Open Source Geospatial Foundation. URL: http://qgis. org) to create our maps. From the University of California at Berkeley library for GeoData (https://geodata.lib. berkeley.edu/), we downloaded polygon shapefiles of the states and municipalities where the hospitals are located and added the hospitals (points) as another layer. Finally, we showed our center with a different mark to highlight the distances between the different hospitals in the network and our center.

\section{Results}

A total of 340 patients were included, 166 for PS and 174 for PPCl. The mean age was $59 \pm 10.8$ years, $87.1 \%$ were male and $12.9 \%$ were female. Regarding medical history, $35 \%$ had diabetes mellitus, $46.8 \%$ hypertension, $17.1 \%$ dislipidemia, $46.2 \%$ were current smokers, and $9.7 \%$ had a previous myocardial infarction (Table 1).

As to the place of residency, $55.29 \%$ came from Mexico City, 29.41\% came from Estado de México, and $5.29 \%$ came from Morelos. We received patients from 60 different hospitals, with a mean distance of $25.2 \mathrm{~km}$, the smallest distance was $1.3 \mathrm{~km}$ and the longest was
$312 \mathrm{~km}$. The mean estimated transfer time was $53 \mathrm{~min}$, being the minimum and maximum of 8 and $263 \mathrm{~min}$, respectively. Moreover, $23.35 \%$ of the patients had their first medical contact at the Instituto Nacional de Cardiología and hospitals who referred the majority of patients to our center were Hospital General "Dr. Manuel Gea González," Hospital General Balbuena, Hospital General "La Perla", Hospital General de Cuernavaca, and Cruz Roja Mexicana (Table 2). Figures 1 and 2 show the geographic distribution of the PS network in the Instituto Nacional de Cardiología.

Regarding the clinical characteristics at admission, no overt differences were found between PS and PPCI groups-even though PPCl presented significantly higher blood pressure levels, these were not clinically relevant. Furthermore, a greater proportion of patients in the PPCI group presented a better Killip-Kimball score compared to the PS group $(p<0.001)$ (Table 3). Likewise, as shown in table 4, laboratory profiles between both groups were similar and most of the tests were among reference values, still some differences were found. For instance, $C$ reactive protein was higher among $\mathrm{PPCl}$ patients, while cardiac dysfunction (NT-PROBNP) and damage (troponin I) markers were significantly higher among PS patients $(p<0.001)$.

In relation to the time of first medical contact, it was 120 min (IQR: 60-225) for PS and $150 \mathrm{~min}$ for PPCI (IQR: 60-270), without significant differences $(p=0.11)$. Moreover, the mean total ischemic time was $347.5 \mathrm{~min}$ (IQR: 200-600) for PS versus 310 min (IQR: 205-557) for $\mathrm{PPCl}(p=0.52)$. Furthermore, for PS patients the mean door-to-needle time was 54 min (IQR: 30-103), and the mean time for pharmacoinvasion was $1440 \mathrm{~min}$ (IQR: 600-2880), while among PPCl patients the time to door-to-device was $72.5 \mathrm{~min}$ (IQR: 60-95). Finally, hospital stay was similar with both strategies, with a mean time of 6 days, and an interquartile range of 3-9 days.

With regard to in-hospital mortality, a total of 20 patients died during the follow-up - 11 patients (6.3\%) who underwent $\mathrm{PCl}$ and nine (5.4\%) who underwent PS $(p=0.82)$. A further subanalysis was made according to the time taken to pharmacoinvasion where the cutoff point was set according to the median value of $1440 \mathrm{~min}$, without differences in mortality (6.56 vs. $5.73 \%$, $p=0.49$ ). Moreover, $96 \%$ of patients from this cohort survived after 6 days of follow-up (Fig. 3). As to the type of post-infarction treatment, mean survival after 6 days was essentially the same between PPCl and PS patients $(95 \%$ vs. $96 \% ; p=0.54)$ as shown in the KaplanMeier curves from figure 4. 
Table 1. Demographic characteristics of patients with STEMI

\begin{tabular}{|c|c|c|c|c|c|c|c|}
\hline \multirow[t]{2}{*}{ Variable } & \multicolumn{2}{|c|}{ Total $(n=340)$} & \multicolumn{2}{|c|}{ PS (n = 166) } & \multicolumn{2}{|c|}{ PPCI (n = 174) } & \multirow[t]{2}{*}{ p } \\
\hline & n & $\%$ & $\mathbf{n}$ & $\%$ & $\mathbf{n}$ & $\%$ & \\
\hline Male & 296 & 87.1 & 148 & 89.2 & 148 & 85.1 & \multirow[t]{2}{*}{0.26} \\
\hline Female & 44 & 12.9 & 18 & 10.8 & 26 & 14.9 & \\
\hline Diabetes & 119 & 35 & 58 & 34.9 & 61 & 35.1 & 0.98 \\
\hline Hypertension & 159 & 46.8 & 72 & 43.4 & 87 & 50 & 0.22 \\
\hline Dyslipidemia & 58 & 17.1 & 21 & 12.7 & 37 & 21.3 & 0.03 \\
\hline Current smoking & 157 & 46.2 & 88 & 53 & 69 & 39.7 & 0.01 \\
\hline Previous smoking & 56 & 16.5 & 23 & 13.9 & 33 & 18.97 & 0.2 \\
\hline Chronic kidney disease & 7 & 2.1 & 4 & 2.4 & 3 & 1.72 & 0.47 \\
\hline Obesity & 77 & 22.7 & 35 & 21.1 & 42 & 24.1 & 0.50 \\
\hline Previous myocardial infarction & 33 & 9.7 & 14 & 8.4 & 19 & 10.9 & 0.43 \\
\hline Previous PCl & 23 & 6.8 & 7 & 4.3 & 16 & 9.2 & 0.05 \\
\hline Previous CABG & 5 & 1.5 & 1 & 0.6 & 4 & 2.3 & 0.20 \\
\hline Heart failure & 3 & 0.9 & 0 & 0 & 3 & 1.7 & 0.08 \\
\hline Valvular heart disease & 2 & 0.6 & 0 & 0 & 2 & 1.2 & 0.26 \\
\hline \multirow[t]{2}{*}{ Atrial fibrillation } & 1 & 0.3 & 0 & 0 & 1 & 0.6 & 0.32 \\
\hline & n & Mean \pm SD & n & Mean \pm SD & n & Mean \pm SD & $\mathbf{p}$ \\
\hline Age (years) & 340 & $59 \pm 10.8$ & 166 & $58.5 \pm 10.9$ & & $60 \pm 11$ & 0.08 \\
\hline
\end{tabular}

PS: pharmacoinvasive strategy; PPCI: primary percutaneous coronary intervention; CABG: coronary artery bypass grafting; SD: standard deviation.

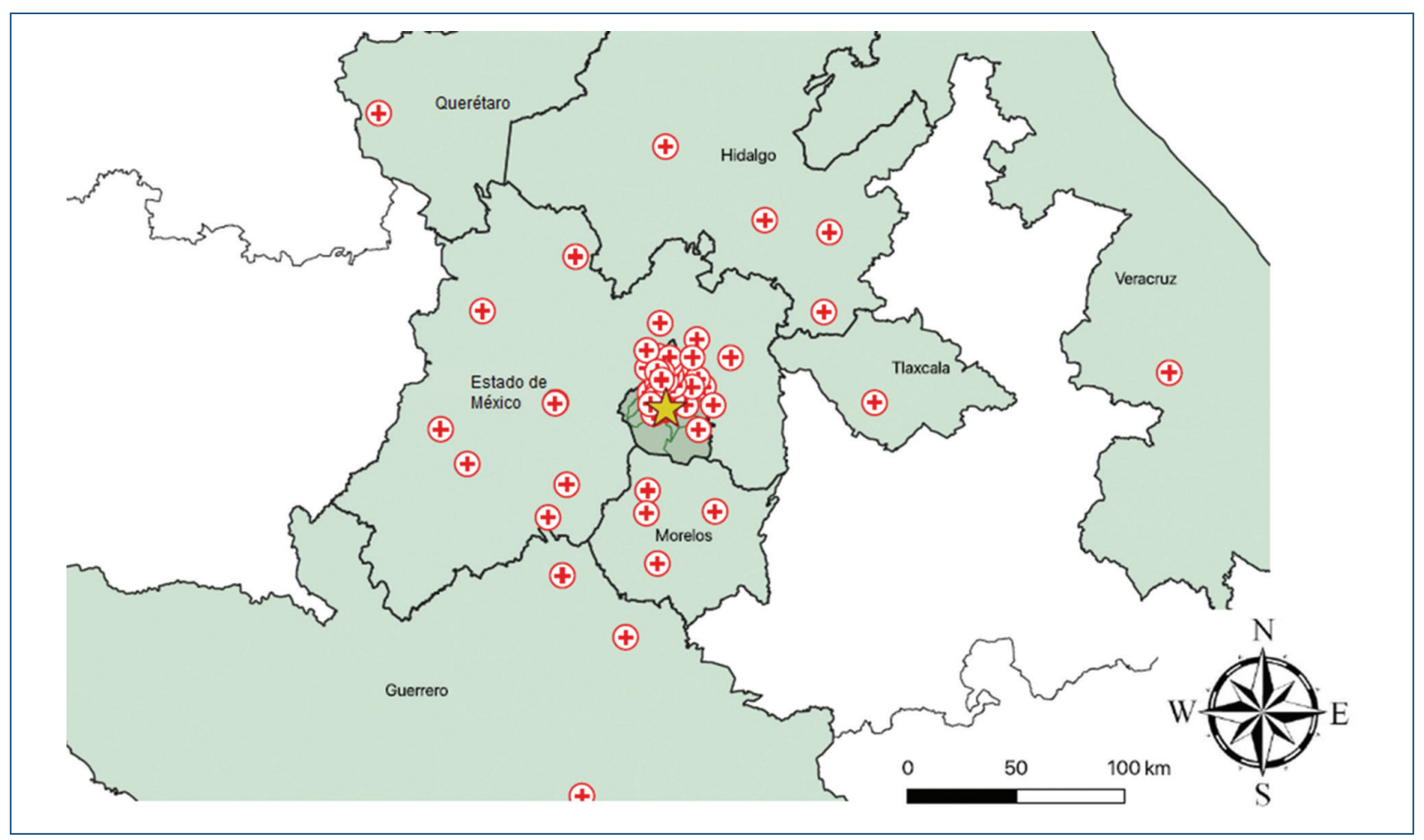

Figure 1. Regional map of places of origin of patients with STEMI. 
Arch Cardiol Mex (Eng). 2021;91(2)

Table 2. Description of the place of first medical contact in patients with STEMI

\begin{tabular}{|c|c|c|c|c|}
\hline Place of first medical contact & n & $\%$ & $\begin{array}{l}\text { Distance to NHI } \\
(\mathbf{k m})\end{array}$ & $\begin{array}{l}\text { Estimated time to } \\
\text { NHI (hh:mm) }\end{array}$ \\
\hline Instituto Nacional de Cardiología & 76 & 22.35 & - & - \\
\hline Médico particular & 55 & 16.17 & - & - \\
\hline Hospital General “Dr. Manuel Gea González” & 42 & 12.35 & 1.3 & 0:08 \\
\hline Hospital General Balbuena & 18 & 5.29 & 19.7 & $0: 41$ \\
\hline Hospital General "La Perla" & 17 & 5 & 25.1 & $0: 53$ \\
\hline Hospital General de Cuernavaca "Dr. José G. Parres" & 13 & 3.82 & 67.7 & $0: 55$ \\
\hline Cruz Roja de México & 9 & 2.65 & 21.9 & 1:40 \\
\hline Hospital General "La Villa” & 9 & 2.65 & 28.3 & $0: 55$ \\
\hline Instituto Nacional de Ciencias Médicas y Nutrición & 6 & 1.76 & 0.85 & 0:06 \\
\hline Hospital de Especialidades "Dr. Belisario Domínguez" & 6 & 1.76 & 12 & $0: 50$ \\
\hline Instituto Nacional de Enfermedades Respiratorias & 5 & 1.47 & 1.4 & 0:08 \\
\hline Hospital General de Texcoco “Guadalupe Victoria” & 5 & 1.47 & 46.5 & 1:06 \\
\hline Hospital General de Tulancingo & 4 & 1.18 & 131 & 2:07 \\
\hline Hospital General “Dr. Enrique Cabrera” & 4 & 1.18 & 20.8 & 0:39 \\
\hline Hospital General de Naucalpan “Dr. Maximiliano Ruiz Castañeda” & 4 & 1.18 & 28.8 & 1:10 \\
\hline Centro Médico de Toluca "Adolfo López Mateos" & 4 & 1.17 & 67.6 & 1:12 \\
\hline Hospital General “Dr. Gustavo Baz Prada” & 3 & 0.88 & 25.3 & $0: 53$ \\
\hline Hospital General de Cuatitlán "José Vicente Villada" & 3 & 0.88 & 56.2 & 1:22 \\
\hline Hospital ISSEMYM Tlalnepantla & 3 & 0.88 & 39.6 & 1:10 \\
\hline Hospital General “Dr. Nicolás San Juan” & 2 & 0.59 & 68.1 & 1:13 \\
\hline Clínica 25, IMSS & 2 & 0.59 & 22.4 & $0: 44$ \\
\hline Hospital General de Huichapan & 2 & 0.59 & 183 & 2:41 \\
\hline Hospital General de Chilpancingo “Dr. Raymundo Abarca Alarcón” & 2 & 0.59 & 251 & $2: 36$ \\
\hline Clínica Médica Mardán & 2 & 0.59 & 16.6 & $0: 36$ \\
\hline Hospital General de Jilotepec & 2 & 0.59 & 114 & 2:07 \\
\hline Hospital General Gregorio Salas & 2 & 0.59 & 19.2 & $0: 45$ \\
\hline Hospital General de México & 2 & 0.59 & 17.3 & 0:36 \\
\hline Hospital General del Valle del Mezquital & 2 & 0.59 & 168 & 2:50 \\
\hline Hospital General de Tláhuac “Dr. Miguel Lima Ramírez” & 2 & 0.59 & 120 & 1:55 \\
\hline Hospital General de Taxco & 2 & 0.59 & 161 & 2:06 \\
\hline Hospital General de Valle de Bravo & 2 & 0.59 & 144 & 2:01 \\
\hline Hospital General de Tlaxcala & 1 & 0.29 & 120 & 1:55 \\
\hline Hospital General de Milpa Alta & 1 & 0.29 & 22.6 & $0: 54$ \\
\hline Instituto Nacional de Cancerología & 1 & 0.29 & 1.2 & 0:06 \\
\hline Hospital General de Cuautla “Dr. Mauro Belauzarán Tapia” & 1 & 0.29 & 90.2 & 1:16 \\
\hline
\end{tabular}


Table 2. Description of the place of first medical contact in patients with STEMI (Continued)

\begin{tabular}{|c|c|c|c|c|}
\hline Place of first medical contact & n & $\%$ & $\begin{array}{l}\text { Distance to NHI } \\
(\mathbf{k m})\end{array}$ & $\begin{array}{l}\text { Estimated time to } \\
\text { NHI (hh:mm) }\end{array}$ \\
\hline Hospital General de Huitzuco & 1 & 0.29 & 180 & 2:07 \\
\hline Hospital General de Jojutla "Dr. Ernesto Meana San Román" & 1 & 0.29 & 128 & 1:37 \\
\hline Hospital Escandón & 1 & 0.29 & 21.2 & $0: 38$ \\
\hline Hospital General de Ixtapan de la Sal & 1 & 0.29 & 122 & 1:46 \\
\hline Hospital Regional " $1^{\circ}$ de 0 ctubre" & 1 & 0.29 & 24.9 & 1:02 \\
\hline Hospital General de Tenancingo" Miguel Hidalgo y Costilla" & 1 & 0.29 & 96.3 & 1:49 \\
\hline Hospital General “Darío Fernández Fierro”, ISSSTE & 1 & 0.29 & 17.5 & 0:30 \\
\hline Clínica Materno Infantil Sagrada Familia & 1 & 0.29 & 30 & $0: 55$ \\
\hline Hospital General del Altiplano & 1 & 0.29 & 104 & 2:10 \\
\hline Instituto Nacional de Neurología y Neurocirugía & 1 & 0.29 & 6.8 & $0: 16$ \\
\hline Hospital General de San Felipe del Progreso & 1 & 0.29 & 147 & 2:05 \\
\hline Hospital General de Ticomán & 1 & 0.29 & 29.1 & 1:20 \\
\hline Hospital General de Zona \#8 & 1 & 0.29 & 11.3 & 0:30 \\
\hline Hospital General de Atizapán & 1 & 0.29 & 40.5 & 1:06 \\
\hline Hospital General "Ajusco Medio" & 1 & 0.29 & 8.9 & $0: 29$ \\
\hline Hospital General de Las Américas & 1 & 0.29 & 43.1 & 1:08 \\
\hline Hospital General de Temixco & 1 & 0.29 & 87.6 & 1:09 \\
\hline Hospital General “Rubén Leñero” & 1 & 0.29 & 28.8 & $0: 48$ \\
\hline Hospital General de Querétaro & 1 & 0.29 & 231 & 2:59 \\
\hline Hospital General de Tacuba, ISSSTE & 1 & 0.29 & 27.7 & $0: 49$ \\
\hline Hospital Municipal de Temascaltepec & 1 & 0.29 & 130 & 2:13 \\
\hline Hospital General de Coatepec & 1 & 0.29 & 312 & $4: 23$ \\
\hline Hospital General de Pachuca & 1 & 0.29 & 114 & 2:08 \\
\hline Hospital General de Ecatepec & 1 & 0.29 & 34.9 & $0: 57$ \\
\hline Hospital Ángeles del Pedregal & 1 & 0.29 & 14.9 & $0: 25$ \\
\hline Hospital Durango & 1 & 0.29 & 25 & $0: 43$ \\
\hline
\end{tabular}

Finally, variables associated with in-hospital mortality for both strategies were assessed through a Cox regression model, wherein blood glucose $>180 \mathrm{mg} / \mathrm{dl}$ (HR 3.73, IC 95\% 1.02-13.56), total ischemic time > $420 \mathrm{~min}$ (HR 3.18, IC 95\% 1.01-10.2), heart rate > 90 bpm (HR 5.46, IC 95\% 1.69-17.59), Killip and Kimbal > II (HR 11.03, IC 95\% 1.42-85.15), and left ventricular ejection fraction < 40\% (HR 3.21, IC 95\% 1.03-10.01) determined a greater mortality risk in the whole cohort (Table 5).

\section{Discussion}

Optimal treatment for STEMI is timely reperfusion. The European Society of Cardiology (ESC) proposes that $\mathrm{PCl}$ is the treatment of choice; however, if the catheterization laboratory is beyond $2 \mathrm{~h}$, the recommended treatment is PS ${ }^{2}$. Unfortunately, Mexico has many limitations, not only in urban infrastructure but also in social and economic development which keeps us away from achieving the proper timing for $\mathrm{PCl}$. As an example of this, we received patients that came from 9 


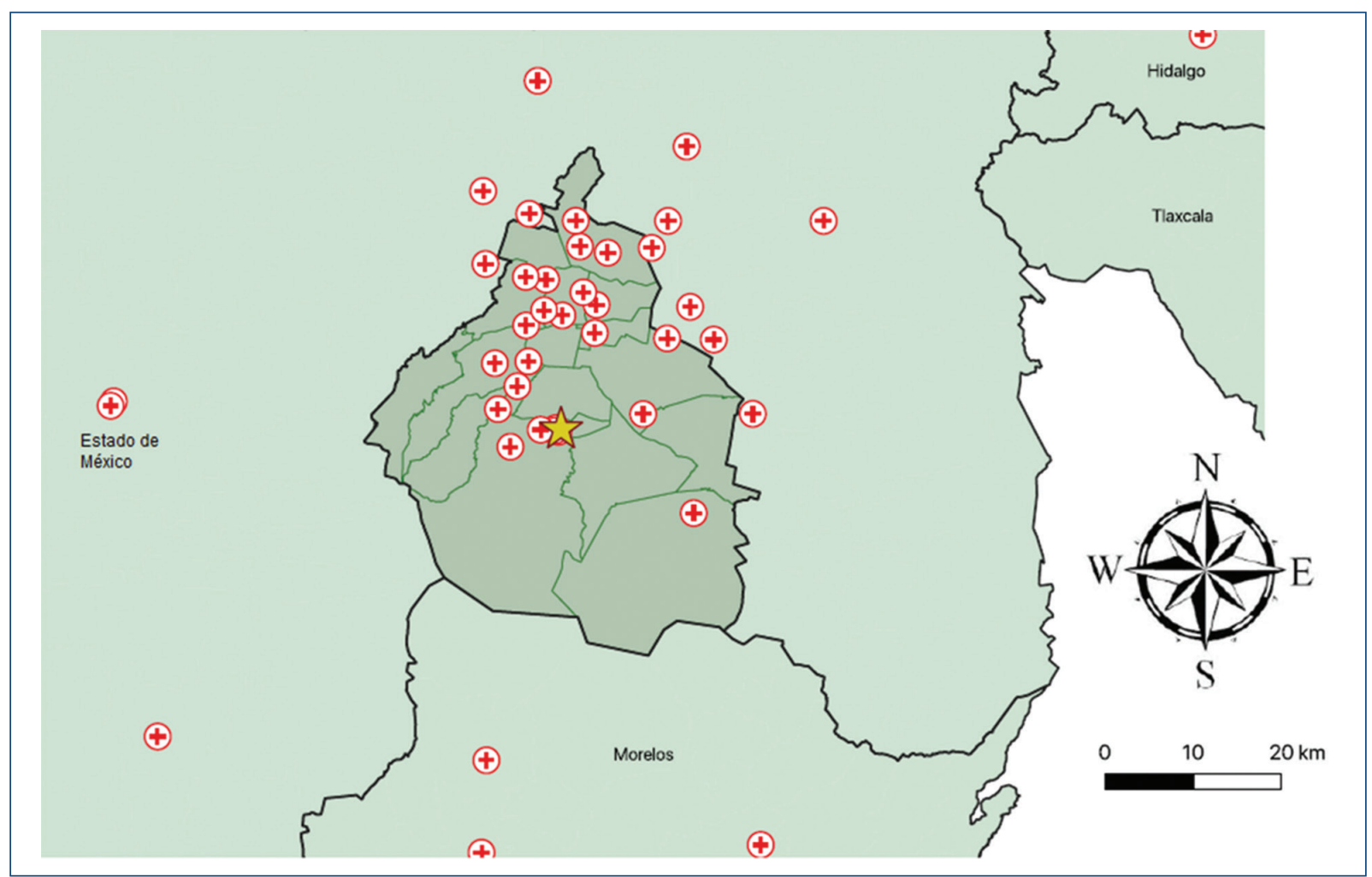

Figure 2. Regional map with a close-up to Mexico City and its metropolitan area indicating the places of first medical contact in patients with STEMI.

Table 3. Clinical characteristics in patients with STEMI

\begin{tabular}{|l|c|c|c|c|}
\hline \multirow{2}{*}{ Variable } & Total $(\mathbf{n}=\mathbf{3 4 0})$ & $\mathbf{P S}(\mathbf{n}=\mathbf{1 6 6})$ & $\mathbf{P P C I}(\mathbf{n}=\mathbf{1 7 4})$ & $\mathbf{p}$ \\
\cline { 2 - 5 } & $\mathbf{n}(\%)$ & $\mathbf{n}(\%)$ & $\mathbf{n}(\%)$ & 0.00 \\
\hline Killip-Kimball I & $181(54.4)$ & $74(45.1)$ & $108(63.5)$ & \\
\hline Killip-Kimball II & $132(39.6)$ & $78(47.6)$ & $54(31.8)$ & \\
\hline Killip-Kimball III & $10(3)$ & $5(3.1)$ & $5(2.9)$ & \\
\hline Killip-Kimball IV & $10(3)$ & 4.3 & $3(1.8)$ & $\mathbf{p}$ \\
\hline Variable & Median (10R) & Median (10R) & Median (10R) & 0.59 \\
\hline Heart rate (bpm) & $75.5(68.5-90)$ & $75.5(70-90)$ & $75.5(68-90$ & 0.87 \\
\hline Respiratory rate (bpm) & $18(16-19)$ & $18(16-19)$ & $18(16-20)$ & 0.01 \\
\hline Systolic pressure (mmHg) & $127(114-147)$ & $126(112-140)$ & $130(117-150)$ & 0.00 \\
\hline Diastolic pressure (mmHg) & $80(70-90)$ & $76.5(70-86)$ & $80(70-93)$ & 0.94 \\
\hline Pulse oximetry (\%) & $92(90-95)$ & $92(90-95)$ & $92(90-95)$ & 0.36 \\
\hline TIMI score & $4(2-5)$ & $4(2-5)$ & $3.5(2-5)$ & 0.19 \\
\hline GRACE score & $125(101-150)$ & $126(106-153)$ & $123(99-147)$ & 0.72 \\
\hline CRUSADE score & $26(18-35)$ & $27(19-35)$ & $26(18-37)$ & \\
\hline
\end{tabular}

PS: pharmacoinvasive strategy; PPCI: primary percutaneous coronary intervention; CABG: coronary artery bypass grafting; SD: standard deviation; IQR: interquartile range. 
Table 4. Laboratory tests in patients with STEMI

\begin{tabular}{|c|c|c|c|c|}
\hline & $\begin{array}{l}\text { Total }(\mathrm{n}=340) \\
\text { Median (IOR) }\end{array}$ & $\begin{array}{c}\text { PS }(n=166) \\
\text { Median (IOR) }\end{array}$ & $\begin{array}{l}\text { PPCI ( }(n=174) \\
\text { Median (IOR) }\end{array}$ & $\mathbf{p}$ \\
\hline Hemoglobin $(\mathrm{g} / \mathrm{L})$ & $15.6(14.4-16.7)$ & $15.35(14.4-16.3)$ & $15.8(14.5-16.9)$ & 0.08 \\
\hline Creatinine $(\mathrm{mg} / \mathrm{dL})$ & $1(0.8-1.2)$ & $1(0.8-1.2)$ & $1(0.8-1.1)$ & 0.99 \\
\hline Urea nitrogen $(\mathrm{mg} / \mathrm{dL})$ & $17(14-23)$ & $18.1(15-25)$ & $16.6(14-21)$ & 0.04 \\
\hline $\mathrm{Na}(\mathrm{mEq} / \mathrm{L})$ & $136(134-138)$ & 136 (134-138) & $136(134-137)$ & 0.30 \\
\hline$C$ reactive protein $(\mathrm{mg} / \mathrm{L})$ & $6.9(2.7-28.7)$ & $13.06(4.26-46)$ & $4.5(2-19)$ & 0.00 \\
\hline Leukocytes $\left(10^{3} / \mu \mathrm{L}\right)$ & $11.7(9.3-14.4)$ & $11.4(9.3-14.7)$ & $11.9(9.2-14.2)$ & 0.82 \\
\hline NT-PROBNP $(\mathrm{pg} / \mathrm{mL})$ & $793.5(222.5-3284.5)$ & $1445(421-3643)$ & $389(100.5-2644)$ & 0.00 \\
\hline Troponin I (ng/mL) & $12.7(0.9-52.8)$ & $35(12-80)$ & $1.85(0.3-14.9)$ & 0.00 \\
\hline Maximum Troponin I (ng/mL) & $64(24-80)$ & $67.9(23.8-80)$ & $62.9(26-80)$ & 0.46 \\
\hline Glucose (mg/dL) & $162.5(1278-238.5)$ & $150(115-230)$ & $174(136-246.8)$ & 0.00 \\
\hline $\mathrm{K}(\mathrm{mEq} / \mathrm{L})$ & $4.1(3.8-4.4)$ & $4.1(3.86-4.5)$ & $4.1(3.8-4.4)$ & 0.07 \\
\hline $\mathrm{Cl}(\mathrm{mEq} / \mathrm{L})$ & $103(100-105.52)$ & $103(101-107)$ & $103(100-105)$ & 0.30 \\
\hline Glycated hemoglobin (\%) & $6.1(5.65-8.2)$ & $6.1(5.6-7.6)$ & $6.1(5.7-8.3)$ & 0.41 \\
\hline Albumin $(\mathrm{g} / \mathrm{dL})$ & $3.6(3.3-3.9)$ & $3.6(3.4-4)$ & $3.7(3.4-3.9)$ & 0.88 \\
\hline Uric acid (mg/dL) & $6.7(5.6-7.86)$ & $6.8(5.8-8.1)$ & $6.4(5.4-7.8)$ & 0.03 \\
\hline Platelets $\left(10^{3} / \mu \mathrm{L}\right)$ & $217(183-259)$ & $209.5(177-257)$ & $221.5(192-263)$ & 0.10 \\
\hline Cholesterol (mg/dL) & $154.9(130-188.9)$ & $153(129.5-186)$ & 157 (131-189) & 0.36 \\
\hline LDL Cholesterol (mg/dL) & $98.3(75-121.8)$ & $99.9(74.4-121)$ & $97.2(75.8-122.6)$ & 0.72 \\
\hline HDL Cholesterol (mg/dL) & $34.4(29.7-40)$ & $34.3(29.2-40.3)$ & $34.5(30.7-40)$ & 0.33 \\
\hline STH (mIU/L) & $1.4(0.7-2.8)$ & $1.35(0.9-2.8)$ & $1.4(0.7-2.9)$ & 0.88 \\
\hline
\end{tabular}

PS: pharmacoinvasive strategy; PPCI: primary percutaneous coronary intervention; SD: standard deviation; IQR: interquartile range; LDL: Iow density lipoprotein; HDL: high density lipoprotein; STH: stimulant thyroid hormone.

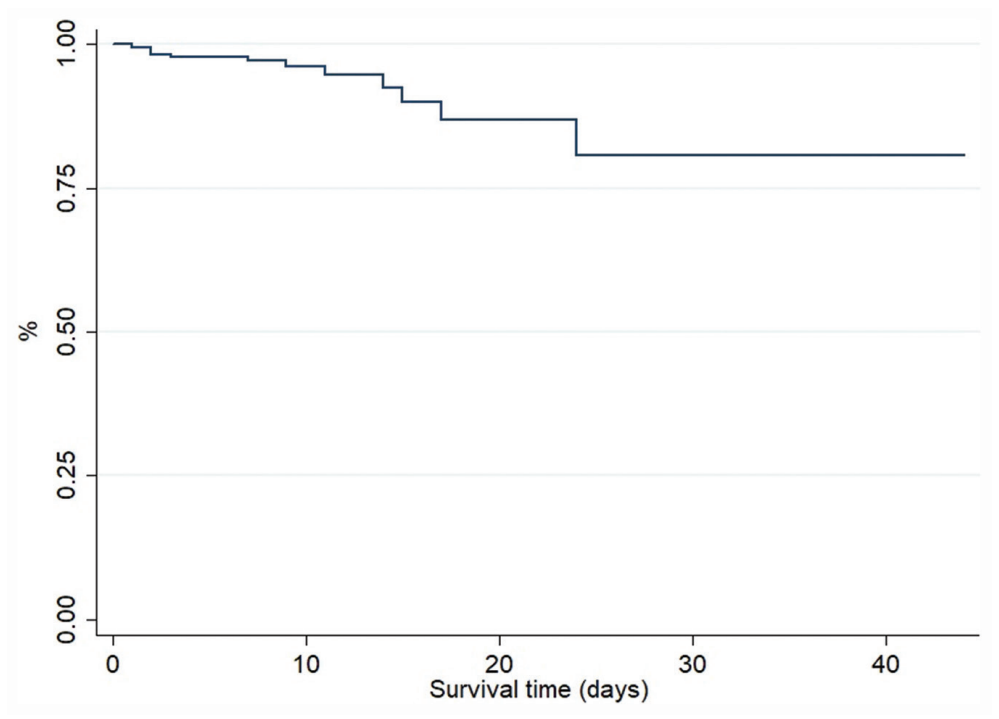

Figure 3. General survival of patients with STEMI. 


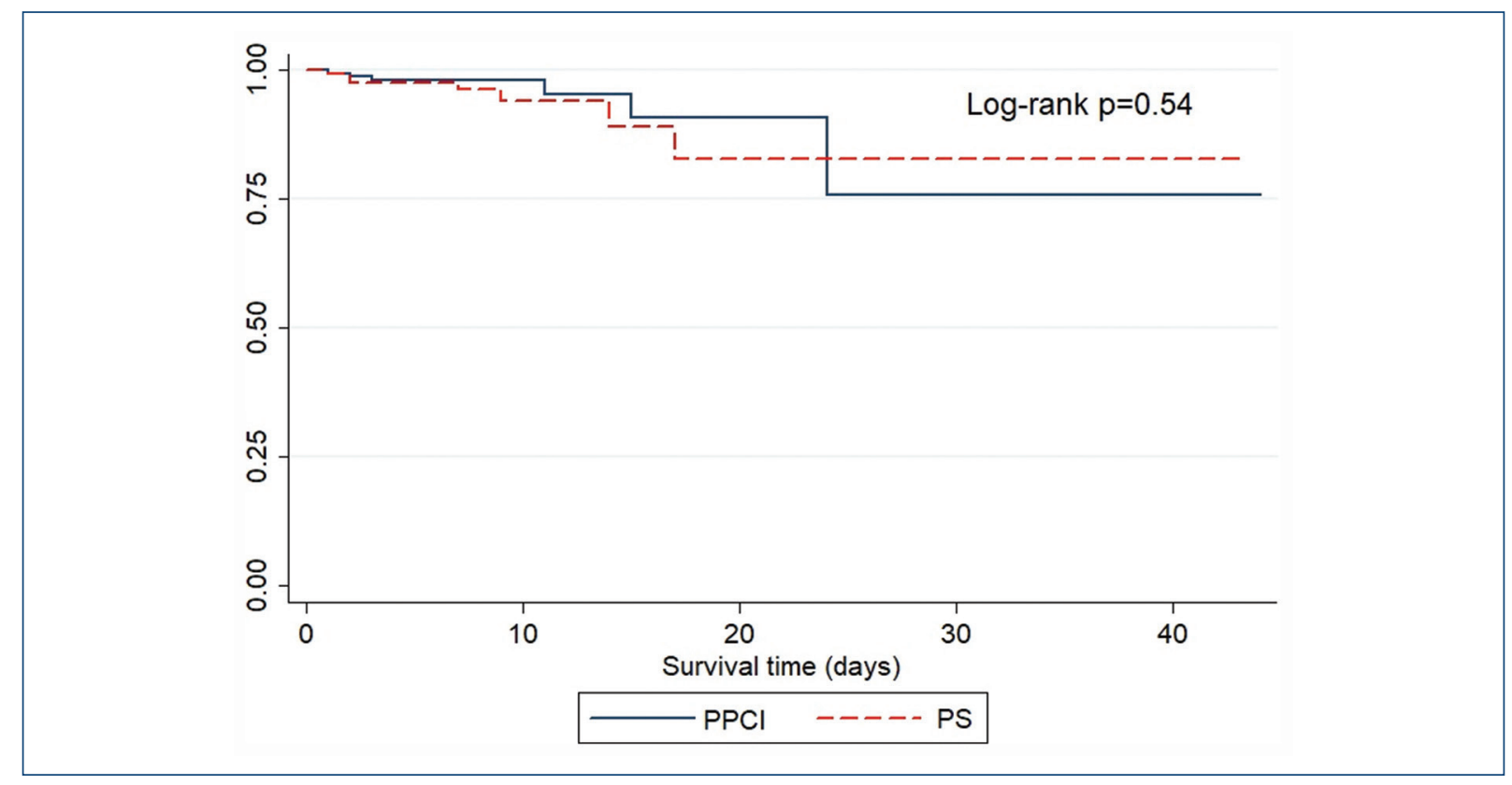

Figure 4. Survival according to the reperfusion strategy in patients with STEMI. PS: pharmacoinvasive strategy; PPCI: primary percutaneous coronary intervention.

Table 5. Cox regression model for prediction of inhospital mortality in STEMI

\begin{tabular}{|l|c|c|c|c|}
\hline Variable & HR & SE & p & $95 \%$ CI \\
\hline Male gender & 2.03 & 2.11 & 0.49 & $0.26-15.55$ \\
\hline Diabetes & 1.75 & 0.94 & 0.29 & $0.61-5.02$ \\
\hline Hypertension & 1.03 & 0.55 & 0.95 & $0.36-2.94$ \\
\hline Chronic kidney disease & 4.26 & 4.48 & 0.16 & $0.54-33.4$ \\
\hline CRP $>5$ mg/L & 1.57 & 0.93 & 0.44 & $0.49-5.02$ \\
\hline Glucose $>180$ mg/dl & 3.73 & 2.45 & 0.04 & $1.02-13.56$ \\
\hline Total ischemia time $>420$ min & 3.18 & 1.89 & 0.04 & $1.01-10.20$ \\
\hline First medical contact $>50 \mathrm{~min}$ & 1.28 & 0.98 & 0.74 & $0.28-5.75$ \\
\hline Heart rate $>90$ bpm & 5.46 & 3.26 & 0.04 & $1.69-17.59$ \\
\hline Systolic pressure $<90 \mathrm{mmHg}$ & 6.75 & 7.12 & 0.07 & $0.85-53.41$ \\
\hline Killip \& Kimball $>$ II & 11.03 & 11.5 & 0.02 & $1.42-85.15$ \\
\hline GRACE score $>140$ & 3.04 & 1.84 & 0.06 & $0.93-9.98$ \\
\hline LVEF < 40\% & 3.21 & 1.86 & 0.04 & $1.03-10.01$ \\
\hline
\end{tabular}

CRP: C reactive protein; LVEF: left ventricular ejection fraction; HR: hazard ratio; SE: standard error; $95 \% \mathrm{CI}$ : $95 \%$ confidence interval.

states and 60 different health facilities, being the most distant the Coatepec General Hospital $(312 \mathrm{~km}$ and a mean estimated transfer time of $4 \mathrm{~h}$ and $23 \mathrm{~min}$ ); moreover, it must be acknowledge that this network covers a big area with a median radius of $25.2 \mathrm{~km}$. This pharmacoinvasive network covers a big area of the Mexican territory and constitutes one of the biggest in the world.

There was a higher proportion of men, diabetes mellitus, hypertension, and active smoking that seemed to surpass the national statistics, and it is striking that there was a lower prevalence of obesity compared to Mexico's National Health and Nutrition Survey (ENSANUT in Spanish) $2012^{25}$.

The time of the first medical contact was higher for $\mathrm{PCl}$ than for PS, however, there were no differences among the total ischemic time even though there was a slight increase in the latter one probably explained by the time of transfer.

The door-to-needle time was found 5 times higher than the time proposed by the ESC guidelines, which emphasizes the fact that training of the medical staff is necessary, because the lower the total ischemic time, the higher the proportion of rescued myocardial tissue ${ }^{2}$. On the other side, the door-to-device time was $72.5 \mathrm{~min}$, which goes hand in hand with the established international guidelines. Furthermore, the time to pharmacoinvasion calculated in our study was 1440 min, equivalent to 1 day, the same time according to the recommendations of the ESC guidelines ${ }^{2,26}$. 
It is important to acknowledge that our patients have longer hospital stays than usual, approximately 6 days, independently of the strategy. The ESC STEMI guidelines recommend a rapid home discharge, especially between the next 48-72 h, in low risk infarctions and when the assurance of a rehabilitation program and follow-up is reliable? .

Within the most relevant data of this study is the in-hospital mortality, represented by 11 patients taken to $\mathrm{PPCl}$ and 9 patients taken to PS, $6.3 \%$ and $5.4 \%$ $(p=0.82)$, respectively. The percentage of survival after STEMI was $94.1 \%$, similar to what Sierra-Fragoso et al. reported in their study, where authors reported in-hospital mortality of $5.1 \%$ in $\mathrm{PS}$ and $5.3 \%$ in $\mathrm{PCl}^{22}$. On the other hand, the RENASCA registry reported a cardiovascular mortality of $14.9 \%$ higher than what we described $^{27}$. Meanwhile, in other international registries, similar mortality has been reported among both strategies with a follow-up to 1 year after the index event, demonstrating that PS is a safe and effective method $^{19,21,28,29}$.

Finally, the data obtained by the Cox regression model for predictors associated with in-hospital mortality were blood glucose $>180 \mathrm{mg} / \mathrm{dl}$, total ischemic time $>420 \mathrm{~min}$, heart rate $>90 \mathrm{bpm}$, Killip-Kimball $>\mathrm{II}$, and left ventricular ejection faction $<40 \%$. This is relevant since we do not have tools to predict in-hospital mortality in our population.

Epidemiological transition has left its mark. Nowadays chronic diseases have a high prevalence and most of them will develop an acute myocardial infarction as a final outcome. Mexico has up to 3 times more in-hospital mortality than the rest of the countries belonging to the Organization for Economic Cooperation and Development (OECD) due to the lack of strategies that does not allow optimal access to medical services and proper timing for treatment. In the national context, the PS headed by the National Heart Institute has proven to be equally effective than $\mathrm{PCl}$ at least for in-hospital mortality, which by now will improve cardiovascular outcomes in the future. This model should keep growing and spreading to the health care centers that have the capacity to perform $\mathrm{PCl}$.

\section{Conclusions}

There were no differences in survival and mortality in STEMI patients treated by means of PPCl or PS. PS is a viable, effective, and safe option for optimal reperfusion in Mexican population according to its social and economic limitations.

\section{Funding}

This research has not received any grant from the public, commercial, or any other non-profit association.

\section{Conflicts of interest}

None.

\section{Ethical disclosures}

Protection of human and animal subjects. The authors declare that no experiments were performed on humans or animals for this study.

Confidentiality of data. The authors declare that they have followed the protocols of their work center on the publication of patient data.

Right to privacy and informed consent. The authors declare that no patient data appear in this article.

\section{References}

1. Thygesen K, Alpert JS, Jaffe AS, Chaitman BR, Bax JJ, Morrow DA, et al. Fourth universal definition of myocardial infarction (2018). Eur Heart J. 2019;40:237-69.

2. Ibanez B, James S, Agewall S, Antunes MJ, Bucciarelli-Ducci C, Bueno $\mathrm{H}$, et al. 2017 ESC Guidelines for the management of acute myocardial infarction in patients presenting with ST-segment elevation: the task force for the management of acute myocardial infarction in patients presenting with ST-segment elevation of the European society of cardiology (ESC). Eur Heart J. 2018;39:119-77.

3. Bentzon JF, Otsuka F, Virmani R, Falk E. Mechanisms of plaque formation and rupture. Circ Res. 2014;114:1852-66.

4. Falk E, Nakano M, Bentzon JF, Finn AV, Virmani R. Update on acute coronary syndromes: the pathologists' view. Eur Heart J. 2013;34:719-28.

5. Saaby L, Poulsen TS, Diederichsen AC, Hosbond S, Larsen TB, Schmi$\mathrm{dt} \mathrm{H}$, et al. Mortality rate in Type 2 myocardial infarction: observations from an unselected hospital cohort. Am J Med. 2014;127:295-302.

6. Chapman AR, Shah AS, Lee KK, Anand A, Francis O, Adamson P, et al. Long-term outcomes in patients with Type 2 myocardial infarction and myocardial injury. Circulation. 2018;137:1236-45.

7. Neumann JT, Sörensen NA, Rübsamen N, Ojeda F, Renné T, Qaderi V, et al. Discrimination of patients with Type 2 myocardial infarction. Eur Heart J. 2017;38:3514-20.

8. Jangaard N, Sarkisian L, Saaby L, Mikkelsen S, Lassen AM, Marcussen $\mathrm{N}$, et al. Incidence, frequency, and clinical characteristics of Type 3 myocardial infarction in clinical practice. Am J Med. 2017;130:862.e9-14.

9. Weir RA, McMurray JJ, Velazquez EJ. Epidemiology of heart failure and left ventricular systolic dysfunction after acute myocardial infarction: prevalence, clinical characteristics, and prognostic importance. Am J Cardiol. 2006:97:13F-25F

10. Grines CL, Cox DA, Stone GW, Garcia E, Mattos LA, Giambartolomei A, et al. Coronary angioplasty with or without stent implantation for acute myocardial infarction. N Engl J Med. 1999;341:1949-56.

11. Stone GW, Brodie BR, Griffin JJ, Morice MC, Costantini C, St Goar FG, et al. Prospective, multicenter study of the safety and feasibility of primary stenting in acute myocardial infarction: in-hospital and 30-day results of the PAMI stent pilot trial. Primary angioplasty in myocardial infarction stent pilot trial investigators. J Am Coll Cardiol. 1998;31:23-30.

12. Keeley EC, Boura JA, Grines CL. Primary angioplasty versus intravenous thrombolytic therapy for acute myocardial infarction: a quantitative review of 23 randomised trials. Lancet. 2003;361:13-20.

13. Piper WD, Malenka DJ, Ryan TJ Jr., Shubrooks SJ Jr., O'Connor GT, Robb JF, et al. Predicting vascular complications in percutaneous coronary interventions. Am Heart J. 2003;145:1022-9.

14. Bartholomew BA, Harjai KJ, Dukkipati S, Boura JA, Yerkey MW, Glazier S, et al. Impact of nephropathy after percutaneous coronary intervention and a method for risk stratification. Am J Cardiol. 2004;93:1515-9.

15. Sadeghi HM, Stone GW, Grines CL, Mehran R, Dixon SR, Lansky AJ, et al. Impact of renal insufficiency in patients undergoing primary angioplasty for acute myocardial infarction. Circulation. 2003;108:2769-75. 
16. Cantor WJ, Fitchett D, Borgundvaag B, Ducas J, Heffernan M, Cohen EA et al. Routine early angioplasty after fibrinolysis for acute myocardia infarction. N Engl J Med. 2009;360:2705-18

17. Aviles $\mathrm{F}$, Alonso J, Beiras A, Vázquez N, Blanco J, Alonso-Briales J, et al. Routine invasive strategy within 24 hours of thrombolysis versus ischaemia-guided conservative approach for acute myocardial infarction with ST-segment elevation (GRACIA-1): a randomised controlled trial. Lancet 2004;364:1045-53.

18. Borgia F, Goodman S, Halvorsen S, Cantor WJ, Piscione F, Le May MR, et al. Early routine percutaneous coronary intervention after fibrinolysis vs. standard therapy in ST-segment elevation myocardial infarction: a meta-analysis. Eur Heart J. 2010;31:2156-69.

19. Armstrong PW, Gerschlick AH, Goldstein P, Wilcox R, Danays T, Lambert $\mathrm{Y}$, et al. Fibrinolysis or primary $\mathrm{PCl}$ in ST-segment elevation myocardial infarction. N Engl J Med. 2013;368:1379-87.

20. Helal AM, Shaheen SM, Elhammady WA, Ahmed MI, Abdel-Hakim AS Allam LE. Primary PCI versus pharmacoinvasive strategy for ST elevation myocardial infarction. Int J Cardiol Heart Vasc. 2018;21:87-93.

21. Sim DS, Jeong MH, Ahn Y, Kim YJ, Chae SC, Hong TJ, et al. Pharmacoinvasive strategy versus primary percutaneous coronary intervention in patients with ST-segment-elevation myocardial infarction a propensity score-matched analysis. Circ Cardiovasc Interv. 2016;9:e003508.

22. Sierra-Fragoso AA, Galván-García JE, Vargas-Ramírez JF, Arboine-Aguirre LA, Muñoz-Consuegra CE, Zapata-Ruiz A, et al. Pharmacoinvasive strategy versus primary angioplasty in patients with acute ST-segment elevation myocardial infarction. Rev Mex Cardiol. 2018;29:126-33.
23. Instituto Nacional de Estadística y Geografía. Encuesta Intercensal 2015, Panorama Sociodemográfico de Ciudad de México 2015. Mexico: Instituto Nacional de Estadística y Geografía; 2015. p. 51.

24. Soto-Estrada G, Moreno-Altamirano L, Díaz DP. Panorama epidemiológico de México, principales causas de morbilidad y mortalidad. Rev Fac Med Univ Nac Auton Mex. 2016;59:9-22.

25. Gutiérrez JP, Rivera-Dommarco J, Shamah-Levy T, Villalpando-Hernández S, Franco A, Cuevas-Nasu L, et al. Encuesta Nacional de Salud y Nutrición 2012, Resultados Nacionales. Cuernavaca, México: Instituto Nacional de Salud Pública; 2012.

26. Huber K, Gersh BJ, Goldstein P, Granger CB, Armstrong PW. The organization, function, and outcomes of ST-elevation myocardial infarction networks worldwide: current state, unmet needs and future directions. Eur Heart J. 2014;35:1526-32.

27. Borrayo-Sánchez G, Rosas-Peralta M, Ramírez-Arias E, Saturno-Chiu G, Estrada-Gallegos J, Parra-Michel R, et al. STEMI and NSTEMI: real-world study in Mexico (RENASCA). Arch Med Res. 2018;49:609-19.

28. Bertomeu V, Cequier A, Bernal JL, Alfonso F, Anguita MP, Muñiz J, et al. Mortalidad intrahospitalaria por infarto agudo de miocardio. Relevancia del tipo de hospital y la atención dispensada. Estudio RECALCAR. Rev Esp Cardiol. 2013:66:935-42.

29. Pinto DS, Frederick PD, Chakrabarti AK, Kirtane AJ, Ullman E, Dejam A et al. Benefit of transferring ST-segment-elevation myocardial infarction patients for percutaneous coronary intervention compared with administration of onsite fibrinolytic declines as delays increase. Circulation. 2011;124:2512-21. 